\title{
A humanistic gift from the Brazilian Emperor D. Pedro II (1825-1891) to the Brazilian nation: the first lunatic asylum in Latin America
}

\author{
Um presente humanitário do Imperador D. Pedro II (1825-1891) à nação brasileira: \\ o primeiro asilo para lunáticos da América Latina
}

Antonio E. Nardi1, Adriana Cardoso Silva1', Jaime E. Hallak², José A. Crippa²

\begin{abstract}
Until the beginning of the 19th century, psychiatric patients did not receive specialized treatment. The problem that was posed by the presence of psychiatric patients in the Santas Casas de Misericórdia and the social pressure from this issue culminated in a Decree of the Brazilian Emperor, D. Pedro II, on July 18, 1841. The "Lunatic Palace" was the first institution in Latin America exclusively designed for mental patients. It was built between 1842 and 1852 and is an example of neoclassical architecture in Brazil, located at Saudade Beach in the city of Rio de Janeiro. In the 1930s and 1940s, the D. Pedro II Hospital was overcrowded, and patients were gradually transferred to other hospitals. By September of 1944, all the patients had been transferred and the hospital was deactivated.
\end{abstract}

Key words: psychiatry, history, madness.

\section{RESUMO}

Até o início do século 19, os pacientes psiquiátricos não recebiam nenhum tipo de tratamento específico. A pressão social da época decorrente do problema representado pela presença dos pacientes psiquiátricos nas Santas Casas de Misericórdia culminou no Decreto do Imperador brasileiro, D. Pedro II, em 18 de julho de 1841. O "Palácio dos Loucos" foi a primeira instituição na América Latina voltada exclusivamente para a assistência aos doentes mentais. Foi construído entre 1842 e 1852, na Praia da Saudade na cidade do Rio de Janeiro, e é um dos expoentes da arquitetura neoclássica do Brasil. Nas décadas de 1930 e 1940, o então Hospital D. Pedro II estava superlotado, tendo sido os pacientes gradualmente transferidos para outros hospitais. Em setembro de 1944, concluiu-se a tranferência de todos os pacientes e o hospital foi desativado.

Palavras-Chave: psiquiatria, história, loucura.

Until the beginning of the $19^{\text {th }}$ century, psychiatric patients did not receive specialized treatment. If they were calm, they would wander the streets; if they were aggressive, they would be arrested and chained in prisons ${ }^{1}$. Only by the middle of the $19^{\text {th }}$ century, the Santas Casas de Misericórdia (Mercy Hospitals) started admitting and taking care of psychiatric patients. This solution, however, was not adequate for the incipient medical specialty that was rising: Psychiatry. The problem that was posed by the presence of psychiatric patients in the Santas Casas de Misericórdia and the social pressure from this issue culminated in a Decree of the Brazilian Emperor, D. Pedro II, on July 18, 1841 ${ }^{1}$. The "Lunatic
Palace"1, as it was called at that time, was the first institution in Latin America exclusively designed for mental patients ${ }^{2}$. It was built between 1842 and 1852, and it is an example of neoclassical architecture in Brazil, located at Saudade Beach in the city of Rio de Janeiro. The project is a result of the collaboration of some of the best architects of that time: Domingos José Monteiro, Joaquim Cândido Guilhobel and José Maria Jacinto Rebelo ${ }^{3}$.

The Lunatic Palace, a symbol of the civilization at that time, was built in the Brazilian imperial capital. This great palace is one of the most significant architectural projects of Brazilian neoclassicism. Occupying a great area, the palace

${ }^{1} \mathrm{MD}$, PhD, Panic \& Respiration Laboratory, Institute of Psychiatry, Universidade Federal do Rio de Janeiro (UFRJ), INCT Translational Medicine (CNPq), Rio de Janeiro RJ, Brazil;

${ }^{2} \mathrm{MD}$, PhD Department of Neuroscience and Behavior, Ribeirão Preto Medical School, Universidade de São Paulo (USP), INCT Translational Medicine (CNPq), São Paulo SP, Brazil.

Correspondence: Antonio E. Nardi; Laboratory of Panic \& Respiration, Institute of Psychiatry, Universidade Federal do Rio de Janeiro; Rua Visconde de Pirajá 407 / 702; 22410-003 Rio de Janeiro RJ - Brasil; E-mail: antonioenardi@gmail.com

Conflict of interest: There is no conflict of interest to declare.

Received 27 July 2012; Received in final form 11 September 2012; Accepted 18 September 2012 
has two floors, four internal gardens, numerous rooms and a beautiful chapel. The D. Pedro II Hospice marked and honored the instauration of the second Brazilian reign of the young Emperor D. Pedro $\mathrm{II}^{2}$. The Emperor enjoyed being considered a philosophical and charitable monarch, a benefactor father of the underprivileged. The construction of the Hospice also marked his presence as a leader who was responsive to the recent changes in Europe in regard to psychiatric patients ${ }^{2}$.

The first patients of the Pedro II Hospice were transferred from the Santa Casa de Misericórdia of Rio de Janeiro. The hospital had a capacity for 150 patients and was immediately filled upon construction ${ }^{1,3}$. The doctors at that time worked on the rehabilitation of the patients. The patients, primarily European descendents, took part in occupational therapy, shoe manufacturing workshops and straw and sewing handcraft $^{3}$. However, the most aggressive patients were controlled by locking them in fortified rooms and restraining them in straitjackets. By the end of the $19^{\text {th }}$ century, the hospital offered workshops to train patients in iron casting, plumbing, electrical engineering, woodworking, carpentry, mattress manufacturing, typography and painting ${ }^{3}$.

With the institution of the Republic in Brazil in 1892, the hospice was renamed the National Hospice of the Alienated ${ }^{3}$. In 1893, an Observation Pavilion was created inside the hospital, which was intended to assist the patients and to aid in the study of psychopathology. This pavilion was designated for academic activities, and psychiatric classes were given to students in the College of Medicine. In 1938, the Institute of Psychopathology and Psychopath Assistance was transferred to the University of Brazil and is currently the Psychiatric Institute of the Federal University of Rio de Janeiro (Figure).

In the 1930s and 1940s, the D. Pedro II Hospital was overcrowded and patients were gradually transferred to other

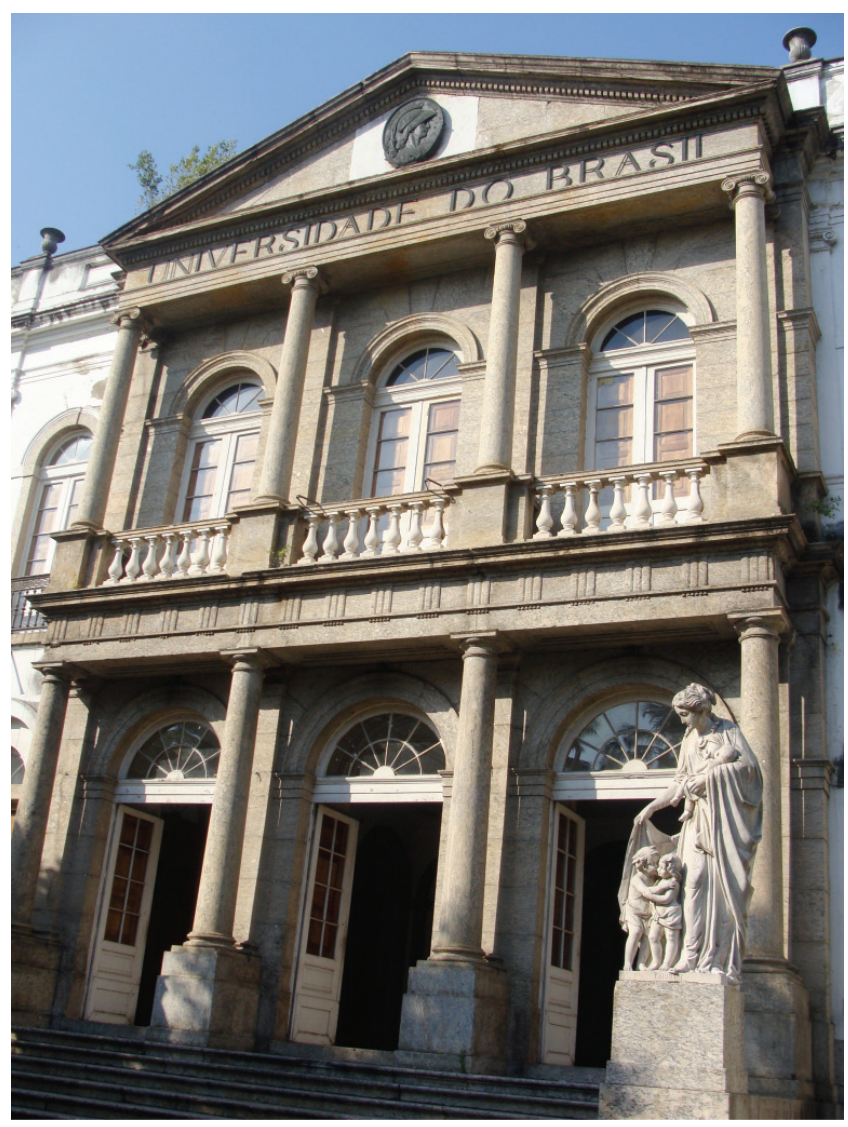

Figure. Photograph by Nardi AE. Front detail of the main entrance.

hospitals $^{1}$. By September of 1944, all the patients had been transferred and the hospital was deactivated and given to the University of Brazil. Currently, the location is part of the Sciences and Culture Forum of the Praia Vermelha Campus of the Universidade Federal do Rio de Janeiro.

\section{References}

1. Gonçalves MS, Edler FC. Os caminhos da loucura na Corte Imperial: um embate historiográfico acerca do funcionamento do Hospício Pedro II de 1850 a 1889. Rev Latinoam Psicopatol Fundam 2009;12:393-410.
2. Barman RJ. Citizen Emperor: Pedro II and the making of Brazil, 18251891. Stanford, CA: Stanford University Press, 1999.

3. Machado R, Loureiro A, Luz R, Muricy K. Danação da norma. Medicina social e constituição da psiquiatria no Brasil. Rio de Janeiro, RJ: Graal 1978. 